\title{
アルミニウム合金を用いたハ二 DESIGN OF HONEYCOMB AND カムとサンドイッチパネル構造 SANDWITCHED PANEL STRUCTURE の設計 \\ 一構造の抽象化による新しい空間表現の 実現一 \\ WITH THE USE OF ALUMINUM ALLOY \\ - A new spacial expression realized by abstracting the structure-
}

\author{
新谷眞人— -1 - 堀田祐介 - $* 2$ \\ 永井拓生— $* 2$ \\ キーワード \\ アルミニウム合金構造, ハニカムコアとサンドイッチパネル, シンボリックな \\ パビリオン, 透過する構造 \\ Keywords : \\ Aluminium structure, Combined with honeycomb and sandwitched panel, \\ Symbolic pavilion, Transparent structure
}

\section{Masato ARAYA - *1 Yusuke HOTTA $-* 2$ Takuo NAGAI - $* 2$}

This Paper reports Honeycomb structure made of aluminum alloy in "Brugge 2002 Pavilion". Honeycomb and Sandwitched-panel have completely different strength and rigidity each other. The layout of these structural elements defines the stress diagrams in the both of structure and expression of the architectural patterns. The transparency of honeycomb, directed by the diagrams, makes the space and the structure of the pavilion abstractive. The synthesis of architectural expression and structural system harmonizes the Pavilion to the town with the medieval atmosphere. The work inherits "Realization of new spatial expression by abstracted structure" in " $K$ residence at Sakura Jousui".

と調和している。この建物は桜上水「K邱」と用途・形・構造は全く 異なるものの、「構造の抽象化による新しい空閒表現の実現」を継承 するものである。

\section{2、ブルージェ・パビリオン設計の経緯と概要}

EU（ヨーロッパ連合）は連合の成立を記念して、毎年ヨーロッパ の都市の中から 2 つを選び、その年の文化首都とする制度を設けた。 選ばれた都市は文化首都にふさわしい事業をおこなう。2002 年、こ の文化首都としてベルギーのブルージェ市が選ばれた。ブルージェ市 は中世において城塞都市を形成していた。掘割の中にかつての町並み を残し、現在は観光都市とし世界的にも有名である。事業の一環とし て市当局は、市発祥の地であり遺跡が埋蔵されているブルク広場に、 シンボリックな施設の建設を計画した。施設建設の主要なテーマの一 つは、中世の面影を残しながら停滞する市中心部の建築デザイン活動 の活性化であった。

ブルク広場には市庁舎をはじめとする中世の建物が面する。設計者 である建築家伊東豊雄によって、この環境に溶け込みながら現代を表 現し、遺跡が埋蔵されている地中に過大な負荷応力を発生させること の無い軽い建築が構想された。その要求を実現できる素材としてアル ミニウム合金が選択された。アルミニウムは工業素材としてわずか 100 年程前に利用が始まった最も現代的な建築素材であり、その比強 度の大きさは重量の軽い構造を可能とし、基礎に与える影響も少ない。 そして構造材表面をそのまま仕上げ面とすることができるという、優 れた特性を持っている。

建物はパビリオンであり特定の用途はもたない。門形の断面が連続 して極めて笚純な直方体をかたちづくる。建物の平面・立面・断面図 を图 1 に示す。地上 1 階で、平面寸法は幅 $6.75 \mathrm{~m}$ 、長さ $16.0 \mathrm{~m}$ 、高さ は $3.75 \mathrm{~m}$ である。建物は人工的に作られた池から立ち上がり、内部は 浮橋を渡って通り抜けることができる。 ビリオンは最も現代的でありながら中世のたたずまいをもつ街並み

\footnotetext{
*1 Oak Structural Design Office

*2 Graduate Student, Science and Engineering, Waseda University
}

*1 (侏)オーク構造設訪

(干150-0031 東京都渋谷区桜丘町29-33 308)

*2 早稲田大学大学院理工学研究科 大学院生 

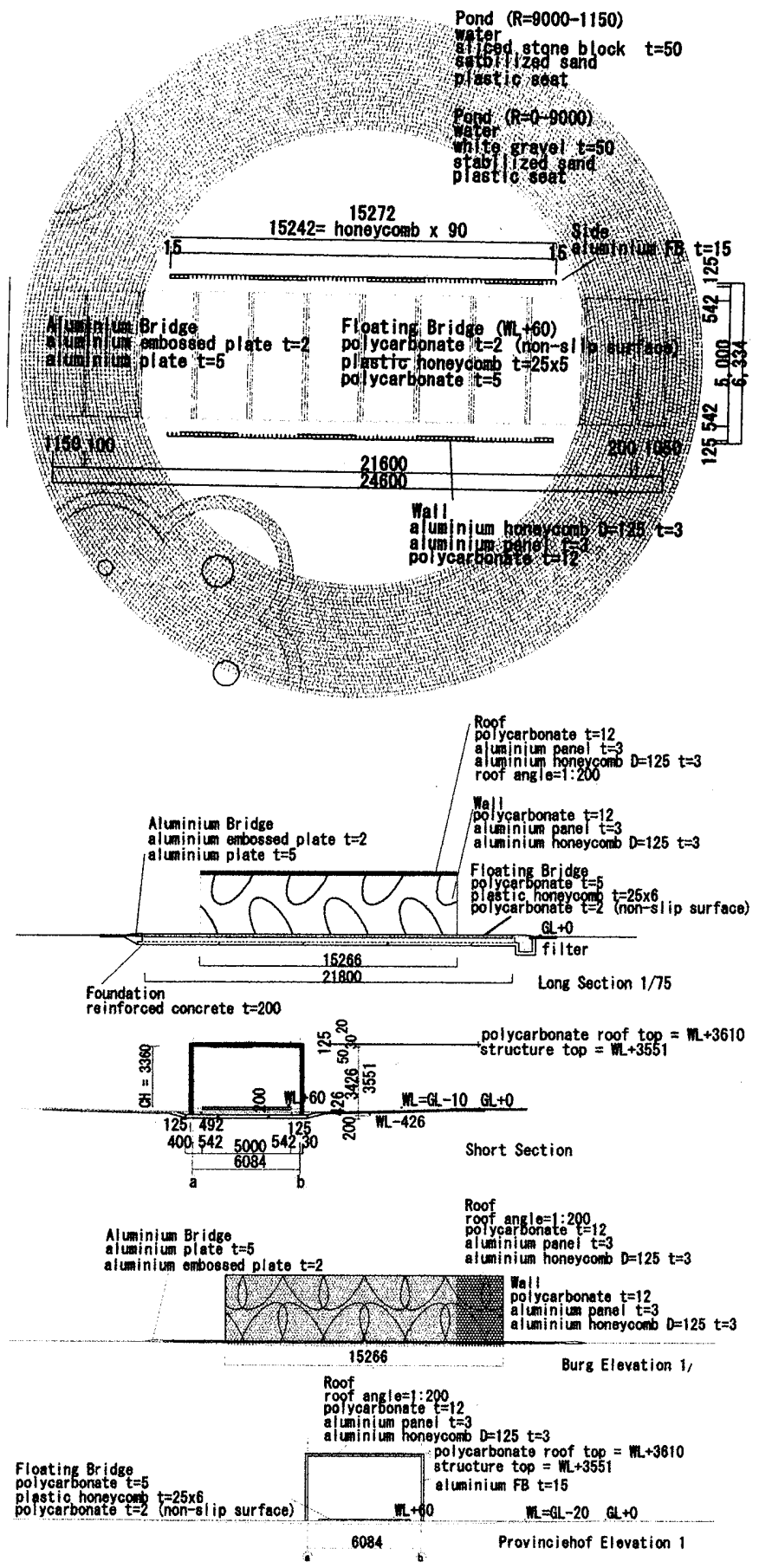

图 1 平面・立面・断面図

「ブルージェ・パビリオン」のハニカム十サンドイッチパネル構造 は、建築分野ではまったく新しい形式である。空間は柱・梁の無い薄 い板状の部材に覆われ、壁も開口部も構造要素であると同時に建築要 素でもある。八ニカム構造は、蜂の巣型の帯板で構成された板状構造 である。サンドイッチパネル構造は、このハニカム構造の上下面に薄 板を貼るように接合した構造である。「ブルージェ・パビリオン」に おけるハニカム十サンドイッチパネル構造は、構造の視觉的消失をよ り発展させた形での建築表現を実現した。图 2 と图 3 に建物の外観お よび内钼写真を示す。

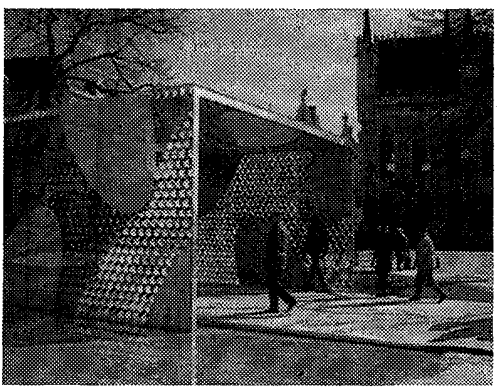

图 2 建物外観写真

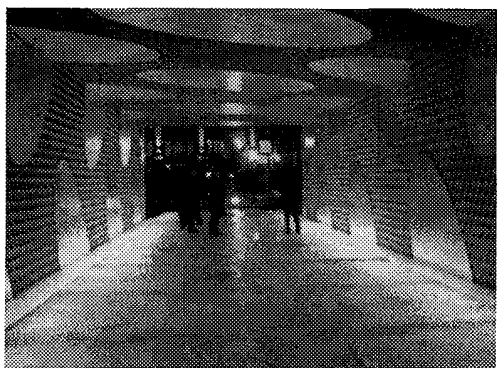

图 3 建物内観写真

3. パビリオンの構造計画

主体構造はアルミニウム合金材を使用したハニカム要素とハニカ ム十サンドイッチパネル要素からなる。パビリオンの平面形は長方形 である。構造はカルバート状の形をしている。雪荷重を含む鉛直荷重 および風による短辺方向の水平力は壁と屋根が構成する門形のフレ 一ムが抵抗する。建物長手方向の風による水平力は壁が負担する。基 礎はべ夕基礎形式の直接基砹である。

カルバート状の構造を連続して配置された門形フレームと考える。 鉛直荷重を受ける門形フレームに生じる曲げモーメントに応じて、強 い構造要素と弱い構造要素を配置すると図 4 の (a)、(b)のようなパタ ーンが生まれる。通常の門形ラーメンの曲げモーメント図を分解して それぞれに応じた構造要素を連続的に並べると図 4(c)のパターンを 得る。最終的にはこれを変形したパターンを基本として設計を進めた。

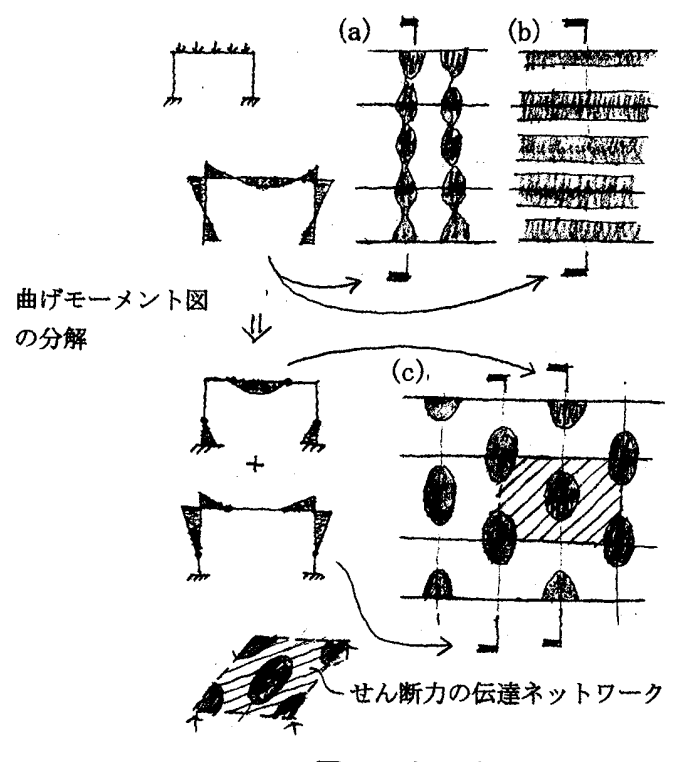

因 4 スケッチ 
連続的に配置された 3 つの異なるパターンの変形状態を分析する ために、カルバート形状の構造体であるブルージェ・パビリオンを図 5 に示す 3 パターンの門形フレームに分類し数值解析を行ない、紙模 型による確蛪を行った。パターン $1:$ 梁端/柱頭をサンドイッチパネ ルで補強、パターン $2:$ 補強の無いハニカムのみ、パターン $3:$ 梁中 央/柱脚をサンドイッチパネルで補強である。

これらを比較すると、パターン $1 、 3$ の変形は小さく、パターン 2 の変形は大きいことが明らかである。しかし図6のようにパターン1、 パターン 2、パターン 3 の順に並べて連結すると、弱いパターン 2 が 介在しても、ハニカム部分でせん断力の伝達がなされ、弱いパターン 2 の変形が抑制されることも明らかになった。

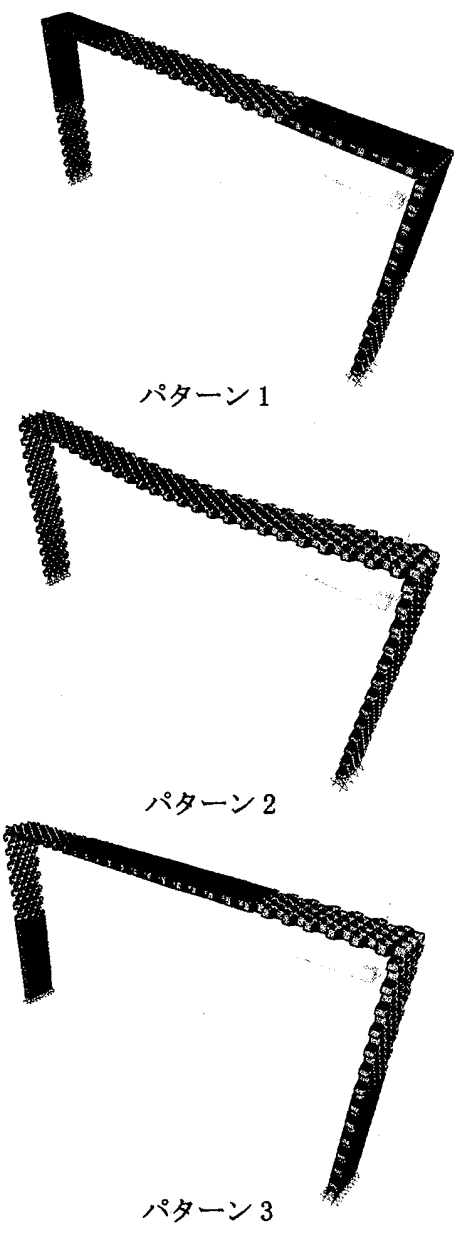

图 5 孤立したパターン

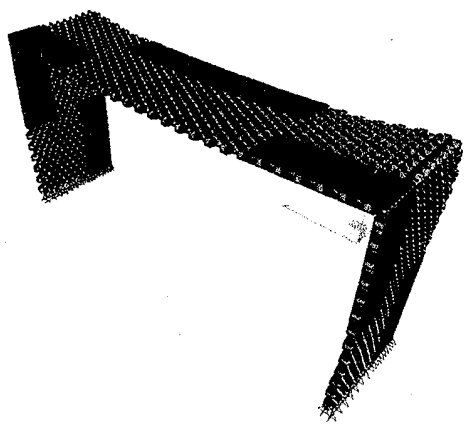

图 6 連結したパターン
图 7 の模型写真において a)は各パターンが孤立した状態を示し、 手前側がパターン 2 である。載せている雑誌は平均重量で各々一冊約 $780 \mathrm{~g}$ である。b)は各パターンを連結した状態である。雑誌は各パタ ーンの上に 3 冊ずつ、計 9 冊載せられている。

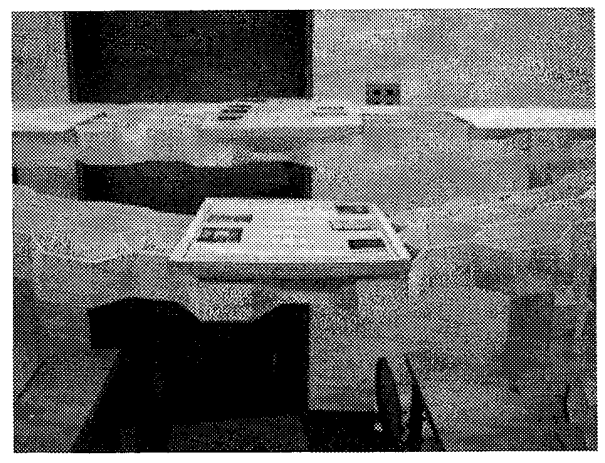

a) パターン 1 3の比較

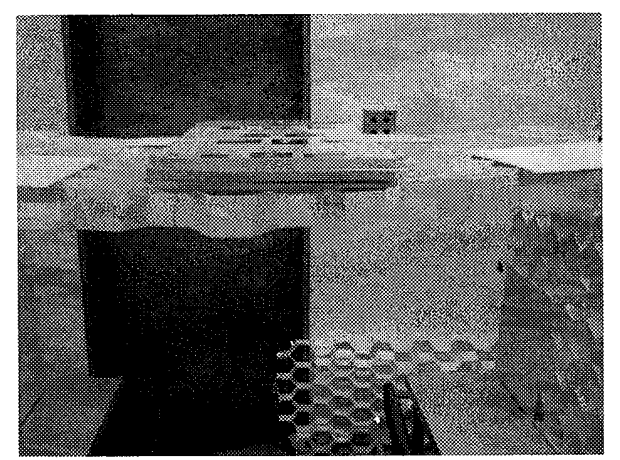

b）パターン 1〜3の連結

図 7 模型写真

4. 構造設計

4. 1 構造計算のプロセス

1）計算手法の妥当性

計算を始めるに際し、計算方法の妥当性を検証するために、線材モ デルと有限要素モデルによる解析法を比較した。もし線材モデルで解 析可能であれば、解析モデルの作成や結果の評価、設計変更への対応 が容易になる。しかし、紙等よる模型の変形とを用い比較した結果、 線材モデルでは八ニカムの挨れ挙動を正確に評価できないことから 有限要素モデルを用いることにした。

2）非線形性の解析

ハニカムの変形がスパンに対して大きいことから、幾何学的非線形 解析を行ない変形・応力を確定した。設計過程で実際の大きさのモッ クアップを製作したところ、載荷後に残留変形が認められた。これら の非線形性はハニカムの摸れ挙動によると推測される。

4. 2 八ニカムとサンドイッチパネルの寸法決定

1) 八ニカム要素

パビリオンにおけるハニカム要素の板厚と板せいは、建築的には壁 や屋根を構成する部材の見付けと奥行きであり、建築表現に大きな影 
郘を与える。しかしハニカム要素単独の棬造はなく、その力学的特性 を定式化した文献もない。このためハ二カム要素の板厚、板せいによ ってハニカム構造の変形がどのように変形するかを解析によって調 べた。图 8 にその結果を示す。

さらに変形とスパンとの関係についても解析し、変形はスパンの 4 乗にほぼ比例することを確認した。

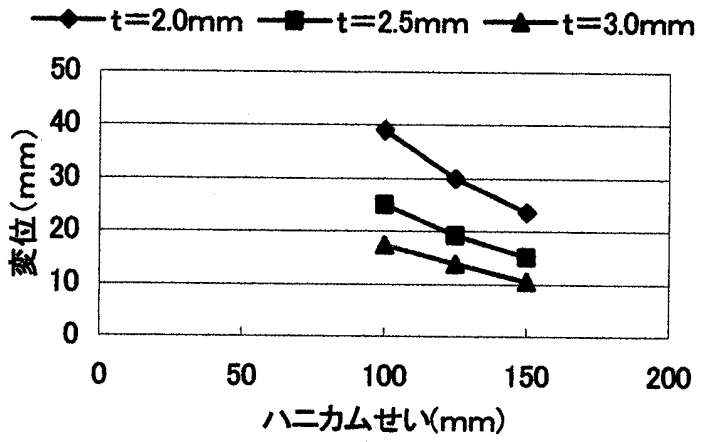

图 8 列数 1 における板厚/板せいによる パラメトリックスタディ

作成したグラフを検討の結果、ハニカム要素の板原を $2.5 \mathrm{~mm}$ 、板せ いを $125 \mathrm{~mm}$ に決定した。

2）サンドイッチパネル

従来、航空機の翼には八ニカムをコアとするサンドイッチパネル構

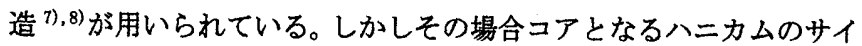
ズと板厚の比は 10 以上と大きく、せん断流による座届を生じること が知られている。今回パビリオンに用いるハニカムのサイズと板厚の 比は 5 と小さく、せん断座屈の心配はない。そしてサンドイッチパネ ル構造要素はパネルがフランジとして働くのみでなく、ハニカム要素 の朕れを拘束するため、剛性は八ニカム要素のみの䍯性を大きく超え

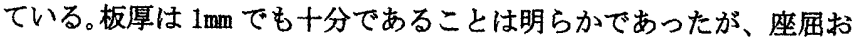
よび接合を考慮して設計は $2 \mathrm{~mm}$ とし、また工場製作に際し入手可能な アルミ板材の板厚が $3 \mathrm{~mm}$ であることから、ハニカム要素とサンドイッ チパネル要素の板厚はすべて $3 \mathrm{~mm}$ とした。

3）サンドイッチパネルとハニカムとの接合方法

サンドイッチパネルはハニカム要素の両面に貼られる。片面は值接 溶接による接合が可能である。もう一面を溶接するにあたり三角形の プレートをハニカム要素に溶接接合する。次に、サンドイッチパネル に孔を明け、三角形プレートと孔周囲を隅肉溶接した。（图 9,10）サン ドイッチパネルと三角プレートの間に生じているせん断力から、必要

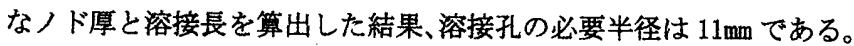

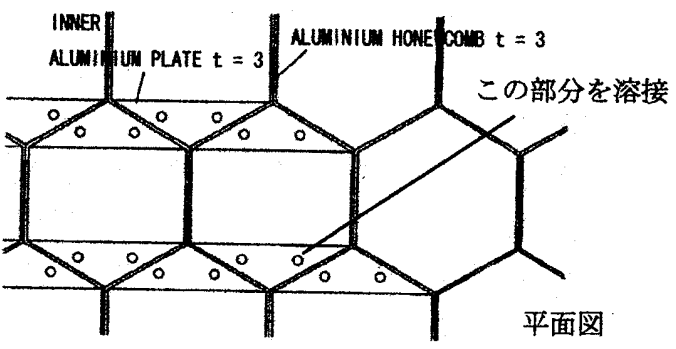

图 9 三角プレートとサンドイッチパネルとの接合詳細

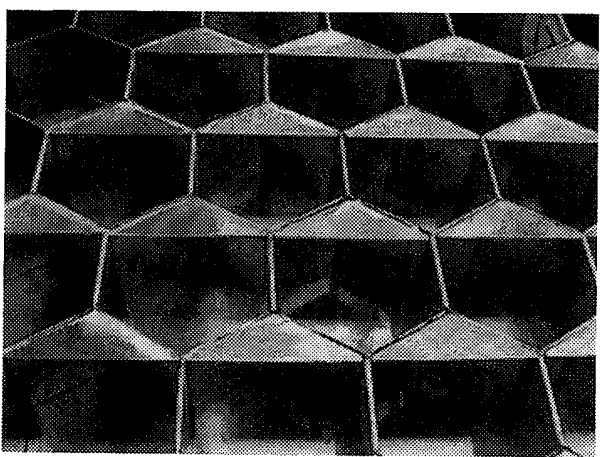

図 10 接合のための三角プレート

この三角プレートは、ハニカム要素の斜辺と直辺の交差する角度を 保持するので、斜辺の㨝れ変形を拘束して要素全体の剛性を高める働 きがある(图 11)。
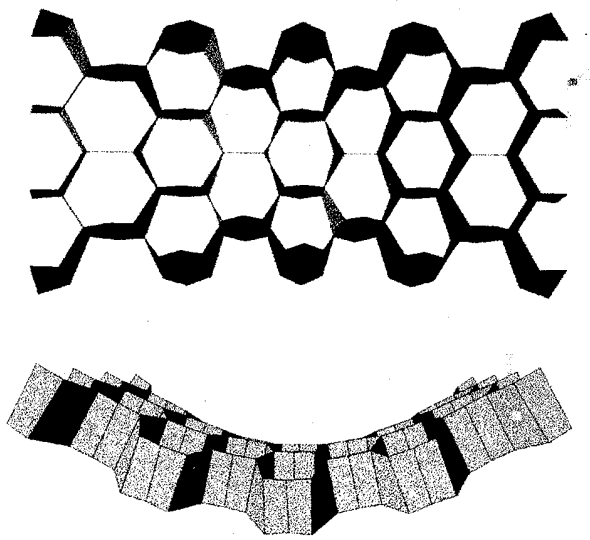

a）三角プレート無しの変形図

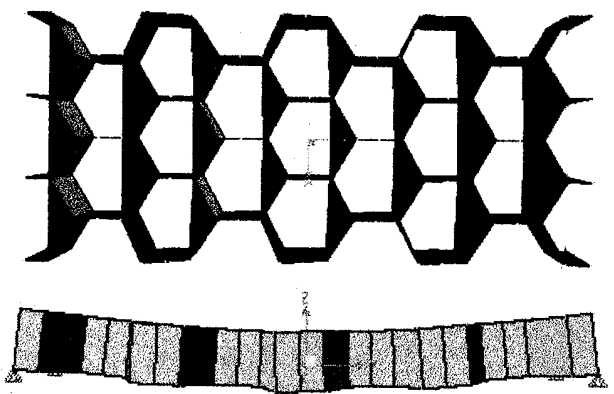

b）三角プレート有りの変形図

図 11 三角プレートの働き

4. 3 部材設計

1）設計規準：設計規準は、Euro Codeに従う。各規定を以下に列記 する。

・構造設計法 : 終局強度法

(Ultimate strength design defined in ENV 1991 第 1 条)

- 荷重条件：ENV1991第 2 条 3 項, 1991 第 2 条 4 項

- 材料強度 : ENV 1999 第 1 条

・使用材料の規定はアルミニウム合金（Code No. 5083-0/H11） 
・荷重および条件

: 固定荷重 : 構造体自重+ガラス重量（DL と表記）

: 積載荷重は考虑しない

: 風荷重（WL と表記）

$\mathrm{Fw}=\mathrm{qref} \times \mathrm{Ce}(\mathrm{Ze}) \times \mathrm{Cd} \times \mathrm{Cf} \times \mathrm{Aref}=0.656 \mathrm{kN} / \mathrm{m}^{2}$ qref $=\rho /(2 \times \mathrm{g}) \times \mathrm{Vref} 2=0.431 \mathrm{kN} / \mathrm{m}^{2}$

: 積雪荷重 : $\mu \mathrm{i} \times \mathrm{Ce} \times \mathrm{Ct} \times \mathrm{Sk}=0.457 \mathrm{kN} / \mathrm{m}^{2} \quad$ （SL と表記）

- 組合せ荷重 : 荷重の組合せは、各荷重に以下に示すような係数を かけて定める。
LC1: $\quad$ DL $\times 1.35$
LC2: DL $\times 1.0$ （偏荷重による変形計算用）
LC3: $\quad \mathrm{DL} \times 1.0+\mathrm{SL} \times 1.5$
LC4: $\quad$ DL $\times 1.0+\mathrm{WL} \times 1.5$

\section{5. 工場製作と現場施工}

八ニカム要素の加工製作について述べる。製作はその大部分を工場 で行った。棈造全体を 3 つ部分に分け、さらに屋根と壁とを別々に 分ける。合計 9 個の部分に分割して製作する。

組立を完了し全体の建て入れと通りを修正して最終形を決定した 後、パネル相互を現場溶接によって接合した。アルミの溶接はデリケ

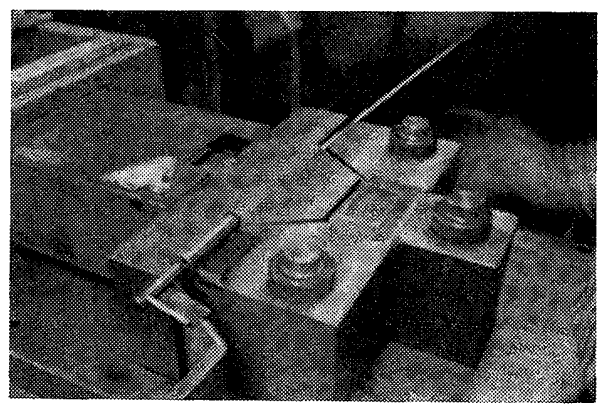

a) アルミ板の折り曲げ

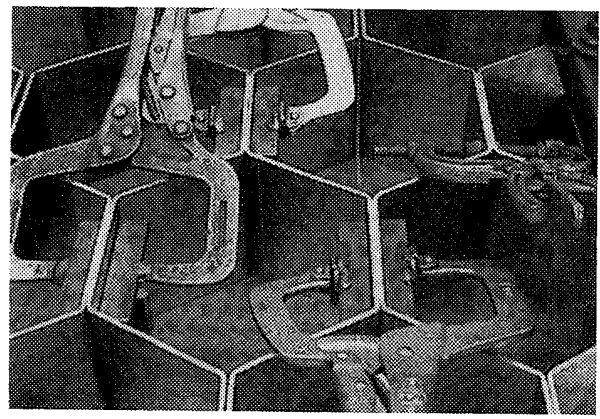

b）八ニカム溶接の準備

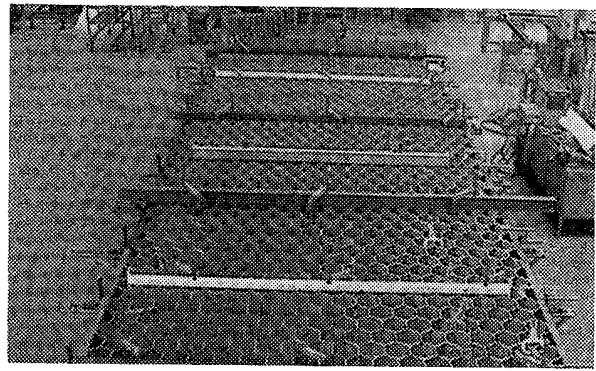

c）溶接ひずみの拘束

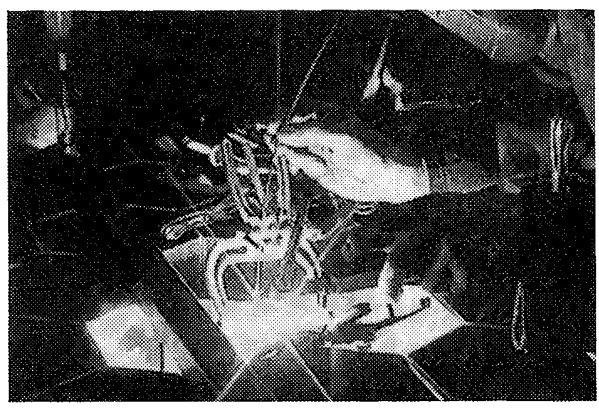

d) 溶接

図 12 八ニカムの加工・製作

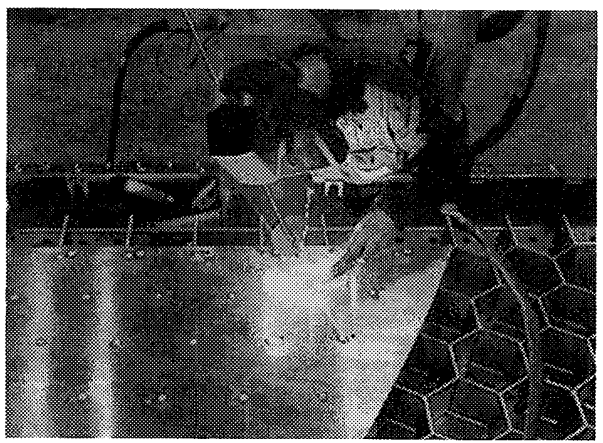

図 13 サンドイッチパネルの製作

一トさが要求され、精度や溶接環境の悪い現場溶接牥難しいとされて きた。製作側はこのため、工場で一貫してこのパビリオンの溶接に従 事していた溶接エ一人を現場溶接にも起用して行った。

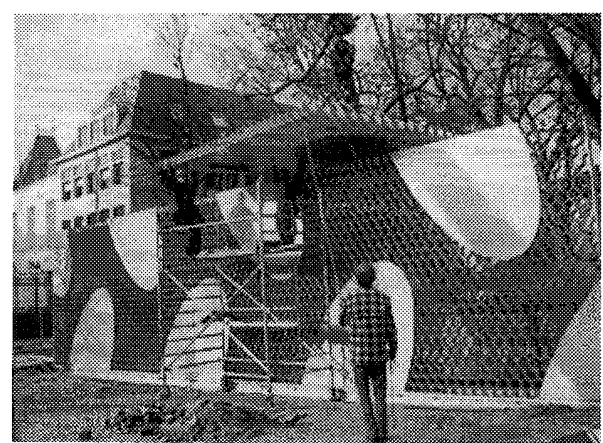

a）現場組立

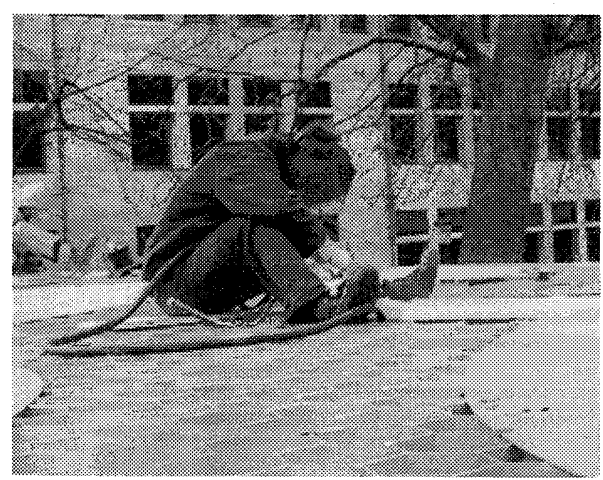

b）現場溶接

图 14 現場における組立と溶接 
アルミの構造部材の製作は大半が工場で行われ、現場で行われるの は単純な接合のみである。パビリオンはハニカム部分が開口部として 残るために、ポリカーボネートで覆っているがそのための作業も軽微 ですむ。現場での組立期間はほぼ 1.5 ケ月である。内分けとしては、 基礎一アルミ取り合い部の調整も含めて、アルミ躯体の組立及び溶接 に 30 日、ポリカーボネードの取り付けに 10 日である。

\section{5. 八ニカム構造の変形について}

設計過程において、紙模型あるいはアルミニウム模型によってハニ カム構造の実際の変形状態を確認した。その結果F EM有限変形モデ ルによる解析値を超える変形及び局部に過大な㐫力が生じ、変形が残 留することが明らかになった(図 15,16)。

これは八ニカム要素の斜め部分の挙動によると推定される。設計段 階では、解析と模型における変形量の比較からパビリオンのスパンを 原設計の $85 \%$ 程度に減じて対态した。

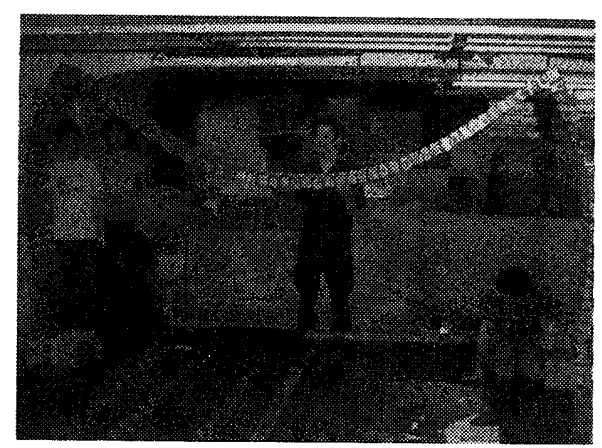

図 15 アルミモックアップによる確認

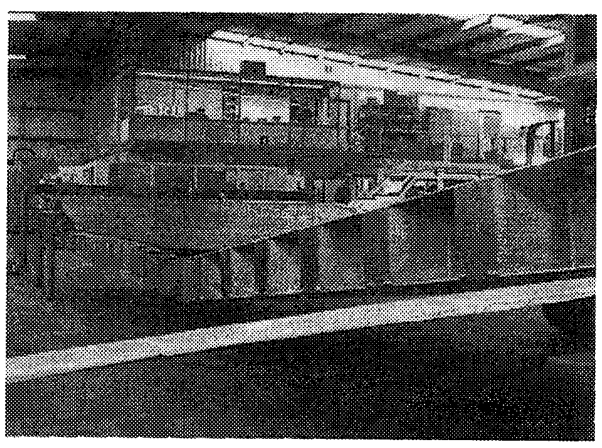

図 16 モックアップ溶接部の剥離

\section{6. 結論}

本報告は、アルミニウム合金の応用による新たな構造の報告である。 この構造は以下のような意義をもつ。

1) 軟らかく延性をもつアルミニウム合金の優れた特性を生かし、折 り曲げた帯板を 2 枚あわせ、背中合わせになった板の緣をI型溶接し て大型のハニカムをつくる。この方法に折り曲げ精度を高め、溶接歪 みを低減し、态力集中部に補強溶接を施すなど、製作における工夫を 行った。こうして製作された広い面状の八ニカムおよび八ニカム構造 の両面に板を溶接したサンドイッチパネルによる構造は、建築分野に おけるアルミニウム合金による新たな構造である。

2) アルミニウムのもつ耐食性そして柔らかなテクスチュアを利用し
て、構造体をそのまま仕上げ面とする。構造要素であるハニカム面と サンドイッチパネル面すなわち透過する部分と不透過の部分はその まま建勧の開口あるいは壁となっている。部位が構造或いは建築とし ての機能境界を消失し、構造が抽象化した新たな空間表現を可能にし た。

3）軽いアルミニウム合金構造によって、埋設している中世の遺跡の 保存に配虑し教地の地中部応力の増加を抑えている。同時に抽象化さ れた建築表現によって、もっとも現代的な建築素材を利用しながら、 ヨーロッパ中世の面影を残すブルージェの街並みに融合した、優れた 建築を創出した。

謝辞

ベルギー国ブルージェ市が 2002 年のEUの文化首都として選ばれ、 このプロジェクトは企画された。プロジェクトが始まってから寒現に 向けて、多くの方々の熱望と尽力によ.りブルージェ・パビリオンは実 現した。このパビリオンの実現に尽くした建築家伊東豊雄氏をはじめ とする多くの関係者に敬意を表すると共に、構造設計の機会を与えら れたことに哚く感謝申し上げる。

参考文献

1）新谷寡人:アルミ構造による空間構造と表現-アルミ構造のこれ までそしてこれからー, シンポジウム最近の建築・土木(橋梁)に おけるアルミ構造と接合, (社) 軽金属溶接構造協会, pp. 49-58, 2003. 2

2）難波和彦、飯島俊比古：「アルミエコハウス」, 新建筑住宅特集, 2000 年 1 月号

3）伊東豊雄、新谷䩀人：「桜上水 $\mathrm{K}$ 㿟」，JA37，2000 年春号

4）新谷真人、岡本憲尚、平田晃久 : アルミニウム合金による耐震 パネルを用いた住宅の構造設計，日本建築学会技術報告集第 11 号, 2000 年 12 月増刊

5）澤井清輔，小野徹郎，石田和人，橋本篤秀：アルミニウム合金 を用いた建築構造に関する研究（その 32）アルミニウム合金十字 型断面アンボンド柱の圧縮座屈試験, 日本建築学会大会学術講 演論文集構造III, pp. 1001-1002, 2000

6）石田和人，小野徹郎，澤井清輔，橋本篤秀: アルミニウム合金 を用いた建築構造に関する研究(その 33)アルミニウム合金十字 型断面アンボンド柱の座屈酎力評価, 日本建築学会学術講演論 文集構造III, pp. 1003-1004, 2000

7）小林繁夫 : 航空機構造力学, 丸善, 1992

8） J.R. Vinson, R. L. Sierakowski : 複合材料の構造力学, 日刊工業 新閶社, 1987

9) S.P. Timochenko: Theory of Elasticity, Mcgrow-Hill, 1934 [2003年10月10日原稿受理 2004年 2 月23日採用決定］ 